\title{
Viral Message in the World of Cyber Marketing and Public Relations
}

\author{
Pijar Suciati \\ Vocational Education Program \\ Communication Studies - Public Relations Laboratory \\ University of Indonesia \\ Depok, Indonesia \\ suciati.pijar@ui.ac.id
}

\author{
Mareta Maulidiyanti \\ Vocational Education Program \\ Communication Studies - Public Relations Laboratory \\ University of Indonesia \\ Depok, Indonesia \\ mareta.maulidiyanti@yahoo.com
}

\begin{abstract}
Since the development of the Internet (Interconnection Networking) aspects of space and time as if it was not a barrier to communication. In addition to offering the ease of sharing information, the Internet (virtual world) also offers various advantages, such as, the absence of hierarchy (one to many, many to many), there is no filter for the message, Interactive (instant feedback, response, and the debate), efficiency in terms of distance and time, free to participate, saving/low cost, and everything is customized. The users of ICT devices, use their technology (gadgets) to access social media like Instagram, Facebook and Twitter. One of the most prominent behavior of Internet users in conveying information is their tendency to share a link or information to friends and other social media users. This behavior causes the spread of information mass and quickly. The phenomenon of spreading the message in this way is known by the name of Viral Marketing (VM) and the resulting message is called viral message, practically is an electronic Word of Mouth (E-WoM) message. This study aims to determine what factors can influence the attitude of audiences to make a message become viral in the online world through the social media and how to create a successful VM for cyber marketing and Public Relations. The methodology of this research is textual and thematic analysis. A set of guidance to plan and create VM for Marketing and Public Relations is the results of this research. Hopefully, by knowing factors to create VM, efforts to make it succesfully viraled, and spesific VM for PR campaign, the company / institution/ organization / individuals can create the good viral message for their marketing/PR purposes.
\end{abstract}

Keywords—viral message; cyber; marketing; public relations

\section{INTRODUCTION}

Since the development of the Internet (Interconnection Networking) aspects of space and time as if it was not a barrier to communication. In addition to offering the ease of sharing information, the Internet (virtual world) also offers various advantages, such as, the absence of hierarchy (one to many, many to many), there is no filter for the message, Interactive (instant feedback, response, and the debate), efficiency in terms of distance and time, free to participate, saving/low cost, and everything is customized. The users of ICT devices, use their technology (gadgets) to access social media like Instagram, Facebook and Twitter. One of the most prominent behavior of
Internet users in conveying information is their tendency to share a link or information to friends and other social media users. This behavior causes the spread of information mass and quickly. The phenomenon of spreading the message in this way is known by the name of Viral Marketing (VM) and the resulting message is called viral message, practically is an electronic Word of Mouth (e-WOM) message.

The viral marketing can be understood as a technique that consists in promoting the brand message, product or service between the user through the interactivity and the co-creation of the value. The viral marketing is characterized by the following features [1]:

- It reduces mainly the costs because the brand message distribution is made by users freely.

- It has more credibility because it is transmitted between users and it is not transmitted from the original source.

- It offers more visibility to the brand picture due to the exponential growing.

- It presents more flexibility in the format because the messages can adopt several forms.

- It is developed through an online environment, especially in the social media due to the participative features.

The organizations should know how to use the social media to find influent, involucrate users and to generate trademark defenders. However, in order to build viral campaigns and to foster the electronic word-of-mouth communication, the confidence should be established and it should be strengthened after that, to solve any reluctance by the possible consumer. It means to go beyond the traditional marketing approach and the advertisement in the websites to cover all the marketing principles of relationships.

\section{LITERATURE REVIEW}

\section{A. Factors to Create Viral Message}

Dellarocas \& Narayan's findings show the density of online ratings exhibits several relationships that have been previously found to exist between aspects of a product and the consumers' propensity to engage in offline WOM related to that product. This study, thus, provides positive evidence for the usefulness of the density metric as a proxy of a purchasing 
population's propensity to en gage in post-purchase online WOM [2]. Petrescu analyzes three of the key ad appeals used in the most successful viral ads currently circulating online: sex, humor, as well as ad informativeness. They hypothesized that an advertisement received from a known interpersonal source, such as a family member, friend or Facebook contact, will lead to a more positive attitude toward the ad and to a higher chance of forwarding the message, than an advertisement from an unknown source. They found all three types of ad appeals significant for both attitude toward the ad and viral intentions [3].

Park's hypothesis 1 through 4 predicted that different types of motivations would be the antecedents of e-WOM behaviors, Motivations to Read, Motivations to Seek, Entertainment Motivation to Share, Sharing Motivation to Share, Benefit Motivation to Share. Hypothesis 5 predicted that opportunity is an external condition which is associated with Reading eWOM messages. Results regarding Hypothesis 6 show that structural capitals are a significant predictor of Seeking eWOM messages. Results regarding Hypothesis 8 show that only Source Risk is significantly related to Reading e-WOM messages while Source Trust is not a significant predictor of this behavior. By testing Hypotheses 9 through 12, the current study found two interesting aspects of the prediction by central cues for e-WOM behaviors. First, Content Topic is a significant predictor of Sharing e-WOM messages from both sources (strong and weak ties), while it is not significantly related to Seeking [4].

The research findings of Arkoudis \& Samanta showed that motivation provided by a company in the Facebook environment through the use of lotteries and discount coupons increases the chances of elderly people spreading the viral message on Facebook. The positive effect is larger in the case of US users than in the European Union [5]. Zernigah \& Sohail's research investigated consumers' attitude towards viral marketing and studied four dimensions that potentially influence consumers' attitude towards viral marketing. Four hypotheses were developed to test the relationship between viral marketing and perceived informativeness, entertainment, irritation, and credibility of viral marketing messages [6].

Hsieh's proposed research model contains three determinants-awareness of persuasive intent, perceived humor, and multimedia effect-designed to explore disseminating behaviors associated with e-WOM marketing. All three determinants had significant influences on attitude toward the received online video and forwarding intentions [7]. The first result of Esmaeilpour \& Aram's research indicates that the message source credibility has significant positive impact on consumer attitude toward brand. It means that if consumer realizes that the source of viral message sent for him is credible, he finds a positive attitude to brand or product of the company. In addition, consumers send these messages to others when they recognize that sources of the message are credible. Therefore, to increase the effectiveness of the word of mouth marketing, companies should increase their professionalism and message source credibility [8].
Cho's findings provide clear empirical evidence for the influence of sender trust and advertiser trust on viral ad effects, but also reveal interesting differences between the effects of sender trust and advertiser trust. Ghosh have defined the concept of social media WOM and explored its influence on the recipient consumer and paved the path for future research in the field of social media WOM. Based on literature review and consequent analysis, we have presented a set of research propositions and a conceptual model [9].

\section{B. Efforts To Make Your Message Successfully Viraled}

Gardner's research sheds light on two VM elements to which researchers have paid little attention. First element is an accurate self-replication of a viral message. Another VM element this study illuminates is the exit rate $(\gamma)$, the probability that individuals currently sharing will stop passing along the message. Apparently, increasing the number of individuals exposed to the target message and the number of consumers passing along the message is critical part of the VM process. [10]. van der Lans' paper develops such a model using the theory of branching processes. The proposed viral branching model allows customers to participate in a viral marketing campaign by [11]: (1) opening a seeding e-mail from the organization, (2) opening a viral e-mail from a friend, and (3) responding to other marketing activities such as banners and offline advertising.

Sabri's paper examines the impact of communication context on controversial taboo ads with respect to the perceived degree of ad tabooness, subjective norms, attitude toward the sponsored brand, and purchase intention. The paper discuss two main findings. First, our results suggest that communication medium context influences perceptions of the tabooness level of the controversial ad, as well as subjective norms [12]. Berger \& Milkman's findings make several contributions to the existing literature. First, they inform the ongoing debate about whether people tend to share positive or negative content. While common wisdom suggests that people tend to pass along negative news more than positive news, our results indicate that positive news is actually more viral [13].

Krizanec \& Dobrinic stated that to make viral marketing successful, it is necessary to devise a quality content and the same content focus to a particular demographic group for which the content is created. If we want to achieve the interest of consumers or potential user of a product or service for content that is created, content must intrigue them in a way that recognizes the passion of the one that created the content. The key to a good viral marketing is good story that requires innovation, creativity and quality of what is offered [14].

\section{Viral Marketing for Public Relations Campaign}

Stephansen addresses how to define viral marketing and how it is currently being used. This initial step will look at previous literature in order to discover a working definition that can be applied to the later research that will be performed. Social networks are a key aspect in viral marketing, and they 
will also be examined. Another takeaway from this research is understanding that campaigns now are more about the big idea rather than one very creative idea that can only be used once [15].

Bampo began this study with three research objectives in mind: first, to understand the mediating effects of differing social network structures on viral marketing campaign performance; second, to develop a process for modelling viral marketing campaigns and then to validate the different models using empirical data, and third, to conduct a number of simulation experiments to predict the spread of a viral message within different kinds of social network structures under different assumptions and scenarios for the empirical campaign, and show how a campaign manager can build and apply a learning platform based upon early performance of the campaign [16]. Hausmann said that arts marketing in general and museum marketing in particular have been the subject of very little research in the field of WOM. The main contribution of the article to museum marketing research is that it identifies and discusses a conceptual framework suitable for museums to stimulate WOM, especially via social media [17].

\section{METHODOLOGY}

In order to perform this research, a textual thematic analysis was performed. The best way to discover how the Viral Marketing works. Therefore, a textual analysis of articles related to viral marketing was performed. From that analysis, themes were found to show ways in which viral marketing has been done. Because of this, the combination method used was created to be able to get a full understanding of this topic. Starting with textual analysis to set a base framework for the thematic analysis that then took place.

\section{A. Textual analysis}

It was used over a content analysis because at this point, there was nothing to quantify yet. The big picture needed to be looked at first. Textual analysis allows for the text to be taken apart and then relate each of the parts to one another [18]. Since a quantitative content analysis did not take place, this can be seen as a qualitative content analysis, insofar as the researcher did, to an extent, coding. But, no statistical tests on the data were performed. Instead, the texts were looked at as a whole and allowed for a richer comparison between them [18]. In this research, the base of the texts was the marketing journals themselves. While they were analyzed as a whole, as some textual analysis literature calls for, the researcher used Berger's classification method and focusing on specific articles that deal directly with the topic at hand [18].

Also, these journals were analyzed according to their content and meaning, not the structure. For this research, the way that the journals presented the text was not as important as what they said in them. Textual analysis allows the researcher to truly examine the way that the words are presented to the readers [19]. Prior states that before the research starts, the angle the text is going to be analyzed from must be decided. For this research, the text was examined in how to perform and create a message to be viraled in cyber world (social media, social network, mobile network, etc.) [20].

\section{B. Thematic Analysis}

The thematic analysis was performed after the textual analysis. The themes were then extracted from that initial analysis. "Thematic analysis is a search for themes that emerge as being important to the description of the phenomenon" [21, p. 3]. The phenomenon that was being dealt with for this research was viral marketing. When performing a thematic analysis, careful reading and rereading of the text is important to uncover the patterns in the data. This allows for proper categories of analysis to emerge. For this study, the researcher categorized into three categories: 1) Factors to Create Viral Message, 2) Efforts to Make Your Message Successfully Viraled, 3) Viral Message for PR Campaign [21].

Once the content was separated into those categories, the data had to be combined and resorted to fit into sub-themes. In the discussion, these themes will be justified from the researcher's perspective in order to give readers a better understanding of why what was pulled out of the data was considered important. All of this lead to how viral marketing is being used for cyber marketing and public relations, which was the ultimate goal [22].

\section{Limitations}

Slight problem with using textual and thematic analysis was the subjective nature of them. Since texts can carry a lot of meaning, different people can interpret the information different ways [13]. It is known that qualitative research cannot be generalized, and the same will be true for this research. For such preliminary work in this area though, that is acceptable. This is the beginning to future research dealing with the viral message for cyber marketing and Public Relations [23].

\section{Analysis}

The guidelines set by the coding sheet let the researcher place the articles into categories according to the topic. Since unlike a content analysis, there was no quantifying, what was done instead was a grouping of trends. The articles were read in a way that looks for where they fall within the preset categories. By separating articles into trends, the thematic analysis could then take place. The thematic analysis looked at each of the broad categories set by the textual analysis and then pulled more specific themes from those. The themes gave a better picture of what was happening to viral marketing. The propositions guided the analysis and were repeatedly referred to in order to be sure that the theory was interrelated to the discussion. The theory was the framework for this entire thesis, and in the end it showed the importance of this study in an academic and practical perspective. 


\section{RESULTS AND DisCUSSIONS}

\section{A. Results}

This research has three propositions, those are (1) Factors to Create Viral Message, (2) Efforts To Make Your Message Successfully Viral, and (3) Viral Message for PR Campaign.

Beyond the propositions, many things about the nature of viral marketing were found. All of these, including the propositions findings, are delineated in the following table.

TABLE I. PROPOSITIONS

\begin{tabular}{|c|c|c|}
\hline $\begin{array}{l}\text { Proposition 1: Factors to } \\
\text { Create Viral Message }\end{array}$ & $\begin{array}{l}\text { Proposition 2: Efforts To } \\
\text { Make Your Message } \\
\text { Successfully Viraled }\end{array}$ & $\begin{array}{l}\text { Proposition 3: Viral } \\
\text { Message for PR } \\
\text { Campaign }\end{array}$ \\
\hline $\begin{array}{l}\text { External Factors (The } \\
\text { Sender's Messages) } \\
\text { 1. Controversy, advertising } \\
\text { and product exclusivity } \\
\text { [2] } \\
\text { 2. Sex, humor, } \\
\text { informativeness [3] } \\
\text { 3. Opportunity to read, } \\
\text { structural capital, } \\
\text { intensity of use, source } \\
\text { risk, content topic [4] } \\
\text { 4. The use of lotteries and } \\
\text { discount coupons } \\
\text { increases the chances of } \\
\text { elderly people spreading } \\
\text { the viral message [5] } \\
\text { 5. Message credibility \& } \\
\text { message appeal [8] } \\
\text { 6. Sender Trust and } \\
\text { Advertiser Trust [9] } \\
\text { 7. Relationship of social } \\
\text { media, Relationship } \\
\text { between social media }\end{array}$ & 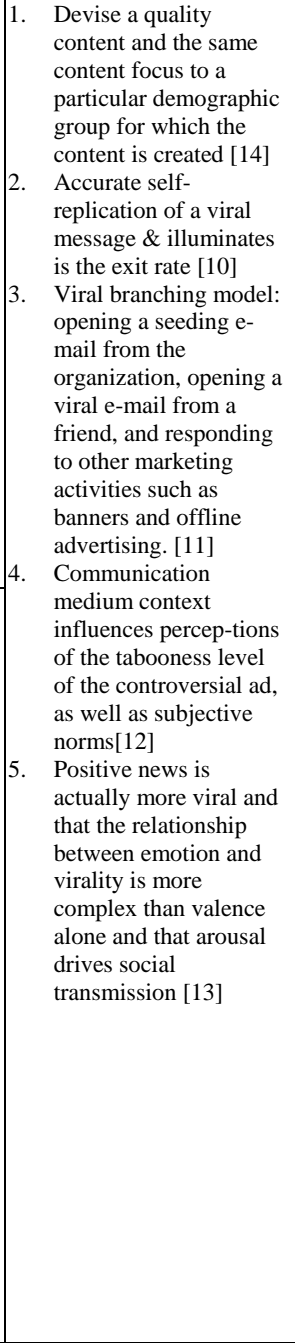 & $\begin{array}{l}\text { 1. Campaigns now are } \\
\text { more about the big idea } \\
\text { rather than one very } \\
\text { creative idea that can } \\
\text { only be used once. This } \\
\text { is an area where } \\
\text { advertising is excelling } \\
\text { [15]. } \\
\text { 2. Three research } \\
\text { objectives in mind: first, } \\
\text { to understand the } \\
\text { mediating effects of } \\
\text { differing social network } \\
\text { structures on viral } \\
\text { marketing campaign } \\
\text { performance; second, to } \\
\text { develop a process for } \\
\text { modelling viral } \\
\text { marketing campaigns } \\
\text { and then to validate the } \\
\text { different models using } \\
\text { empirical data: and third, } \\
\text { to conduct a number of } \\
\text { simulation experiments } \\
\text { to predict the spread of a } \\
\text { viral message within } \\
\text { different kinds of social } \\
\text { network structures under } \\
\text { different assumptions } \\
\text { and scenarios for the } \\
\text { empirical campaign, and } \\
\text { show how a campaign } \\
\text { manager can build and } \\
\text { apply a learning } \\
\text { platform based upon } \\
\text { early performance of the } \\
\text { campaign [16] } \\
\text { 3. Recommendations by } \\
\text { third parties are one of } \\
\text { the main reasons. With } \\
\text { regard to viral effects } \\
\text { and the scarcity of } \\
\text { organizational resources, } \\
\text { the focus should be on } \\
\text { applications with high } \\
\text { user numbers (such as } \\
\text { Facebook, Twitter and } \\
\text { YouTube) [17] }\end{array}$ \\
\hline
\end{tabular}

\section{B. Discussions}

Factors that create a viral message devided into two categories, they are internal factors (from inside the recievers) and external factors (from the senders). The first internal factors are the motivations from the message recievers, such as; motivations to read, motivations to seek, entertainment motivation to share, sharing motivation to share, benefit motivation to Share. Another internal factors are something percieved by the recievers, such as percieved informativeness, entertainment, and credibility of VM messages awareness of persuasive intent, perceived humor, multimedia effect, perceived risk, brand attitude, and finally the purchase intention. The external factors that create the viral message are; message with controversy, great traditional advertising and product exclusivity. The spesific content such as sex, humor, informativeness tend to be viral. The spesific condition of the reciever such as opportunity to read, structural capital, intensity of use, source risk, content topic are also create environment for a message to be viral. Despite the young user of the oline world, if we targeted the elders, we can use the lotteries and discount coupons to increase the chances of elderly people spreading the viral message.

After we know the factors that build the message to be viral, we can enhance the message viralness by doing spesific things to get it successfully viraled, such as devise a quality content and the same content focus to a particular demographic group for which the content is created. There are may character and culture in the world's demographic, create a message that match the target audience's characteristic and culture to get it viral. Another way is, make sure the message has accurate self-replication \& illuminates is the exit rate There are a model that helps us to enhance the viral message, Viral branching model: opening a seeding e-mail from the organization, opening a viral e-mail from a friend, and responding to other marketing activities such as banners and offline advertising. Communication medium context influences perceptions of the tabooness level of the controversial ad, as well as subjective norms. Sometimes sender sanely create the controversial ones just to get it viral. They also must know that positive news is actually more viral and that the relationship between emotion and virality is more complex than valence alone and that arousal drives social transmission Another way, is making sure the message credibility \& message appeal, also the sender trust and Advertiser Trust. Don't forget to create relationship of social media and relationship between social media

Special highligts of this research is about viral message in the world of Public Relations. It is unique because it has different nature than marketing and advertising (above the line). Public Relations is all about creating messages with value, norm, reliable and comprehensive, then communicate them in a different campaign (below the line). Campaigns now are more about the big idea rather than one very creative idea that can only be used once. This is an area where advertising is excelling. Three research objectives in mind: first, to understand the mediating effects of differing social network structures on viral marketing campaign performance; second, to develop a process for modelling viral marketing campaigns and then to validate the different models using empirical data: and third, to conduct a number of simulation experiments to predict the spread of a viral message within different kinds of social network structures under different assumptions and scenarios for the empirical campaign, and show how a campaign manager can build and apply a learning 
platform based upon early performance of the campaign. Recommendations by third parties are one of the main reasons. With regard to viral effects and the scarcity of organizational resources, the focus should be on applications with high user numbers (such as Facebook, Twitter and YouTube).

These results can be a set of guidance, for academicians to create further research and a set of guidance to plan and create viral message for Marketing and Public Relations practitioners. Hopefully, by knowing factors to create viral message, efforts to make it succesfully viraled, and spesific message for PR campaign, the company/institution/ organizations/individuals can create the good viral message for their marketing/PR purposes.

\section{ACKNOWLEDGEMENT}

I'd like to show my gratitude to my second author for sharing their pearls of wisdom and knowledge with me during the making of this research. I am also immensely grateful to my students Fajar Maulana Triawinata for your support on doing the journal reading. Any errors and imperfections in this research are my own and should not tarnish the reputations of these esteemed persons mentioned.

\section{REFERENCES}

[1] M. Petrescu, Viral advertising: Conceptual and empirical examination of antecedents, context and its influence on purchase intentions. Florida Atlantic University, 2012.

[2] C. Dellarocas, and R. Narayan, "A statistical measure of a population's propensity to engage in post-purchase online word-of-mouth," Statistica. Sci., vol. 21, no. 2, pp. 277-285, 2006.

[3] M. Petrescu, P. K. Korgaonkar, T. F. Mangleburg, and A. R. Root, Ad Appeals in the Context of Viral Advertising. In Thriving in a New World Economy. Cham: Springer, 2016, p. 95.

[4] S. Park, "An Investigation of Electronic Word-Of-Mouth (e-WOM) Dynamics on Social Networking Services (SNSs) Based on the Integrative Theoretical Framework,” Ph. D. dissertation, Northwestern Univ., 2016.

[5] N. Arkoudis and I. Samanta, "Behaviour of Elderly Users on Facebook toward Viral Marketing Messages: A Comparative Study Between the European Union and the United States,” J. of Marketing and Operations Manage. Res., vol. 2, no. 1, 2012.

[6] K. I. Zernigah and K. Sohail, "Consumers' Attitude Towards Viral Marketing In Pakistan,” Manage. and Market., vol. 7, no. 4, pp. 645662, 2012.
[7] J. K. Hsieh, Y. C. Hsieh, and Y. C. Tang, "Exploring the disseminating behaviors of eWOM marketing: persuasion in online video,” Electron. Commerce Res., vol. 12, no. 2, pp. 201-224, 2012.

[8] M. Esmaeilpour, and F. Aram, "Investigating the impact of vira message appeal and message credibility on consumer attitude toward the brand,” Manage. and Market., vol. 11, no. 2, pp. 470-483, 2016.

[9] S. Cho, J. Huh, and R. J. Faber, "The influence of sender trust and advertiser trust on multistage effects of viral advertising," J. of advert., vol. 43, no. 1, pp. 100-114, 2014.

[10] J. T. Gardner, K. Sohn, J. Y. Seo, and J. L. Weaver, “A sensitivity analysis of an epidemiological model of viral marketing: when viral marketing efforts fall flat,” J. of Market. Develop. and Competitiveness, vol. 7, no. 4, pp. 25-46, 2013

[11] R. van der Lans, G. van Bruggen, J. Eliashberg, and B. Wierenga, “A viral branching model for predicting the spread of electronic word of mouth,” Market. Sci., vol. 29, no. 2, pp. 348-365, 2010.

[12] O. Sabri, "Does Viral Communication Context Increase the Harmfulness of Controversial Taboo Advertising?” J. of bus. ethics, vol. 141, no. 2, pp. 235-247, 2017.

[13] J. Berger, and K. L. Milkman, "What makes online content viral?” J. of Market. Res., vol. 49, no. 2, pp. 192-205, 2012.

[14] B. Krizanec and D. Dobrinic, "Consumer Perception of Viral Marketing - Example of Croatian Market,” Economic and Social Development: Book of Proceedings, 2016.

[15] K. Stephansen, Diffusion of viral marketing into the world of public relations. University of Missouri-Columbia, 2008.

[16] M. Bampo, M. T. Ewing, D. R. Mather, D. Stewart, and M. Wallace, "The effects of the social structure of digital networks on viral marketing performance,” Inform. Syst. Res., vol. 19, no. 3, pp. 273-290, 2008.

[17] A. Hausmann, "The importance of word of mouth for museums: An analytical framework,” Int. J. of Arts Manage., vol. 14, no. 3, pp. 32-43, 2012.

[18] A. A. Berger, Essentials of Mass Communication Theory. London: SAGE Publications, 1995

[19] N. Fairclough, "Discourse and Text: Linguistic and Intertextual Analysis within Discourse Analysis,” Dicourse and Society, vol. 3, no. 2, pp. 193217, 1992.

[20] L. Prior, Doing Things with Documents. In Silverman, D. (Ed.) Qualitative Research: Theory, Method and Practice, 2nd ed., London: SAGE Publications, 2004, pp. 77-94.

[21] J. Fereday and E. Muir-Cochran, "Demonstrating Rigor Using Thematic Analysis: A Hybrid Approach to Inductive and Deductive Coding and Theme Developments,” Int. J. of Qualitat. Meth., vol. 5, no. 1, pp. 1-13, 2006.

[22] J. Arson, “A Pragmatic View of Thematic Analysis,” The Qualitative Report, vol. 2, no. 1, pp. 1-2, 1994.

[23] D. W. Stacks, Primer of Public Relations Research. New York: The Guilford Press, 2002. 